\title{
Reduction of nematode damage by root colonization with arbuscular mycorrhiza (Glomus spp.) in tomato-Meloidogyne incognita (Tylenchida: Meloidogynidae) and carrot-Pratylenchus penetrans (Tylenchida: Pratylenchidae) pathosystems
}

\author{
Miguel Talavera, Kenji Itou ${ }^{1}$ and Takayuki Mizukubo ${ }^{1}$ \\ Estación Experimental del Zaidín, CSIC. Profesor Albareda, 118008 Granada, Spain \\ ${ }^{1}$ Nematology Lab, National Agricultural Research Center, Tsukuba, Ibaraki 305-8666, Japan
}

(Received 12 December 2000; Accepted 6 April 2001)

\begin{abstract}
Pot studies on the effects of mycorrhizal root colonization on plant growth and nematode reproduction in tomatoMeloidogyne incognita and carrot-Pratylenchus penetrans pathosystems were carried out. The mycorrhizal fungus Glomus mosseae did not protect tomato plants inoculated with the pathogen M. incognita when it was inoculated simultaneously with the mycorrhiza, as plants inoculated with $M$. incognita died before harvest. On the other hand, when tomato seedlings were inoculated with the nematode three weeks after mycorrhization, colonization of tomato roots by $G$. mosseae compensated for the reduction of plant growth caused by M. incognita infection. Tomato shoot weight was $24 \%$ greater and gall index $33 \%$ lower than plants inoculated with the nematode alone, and final soil densities of $M$. incognita were reduced by $85 \%$ when tomato roots were colonized by the mycorrhiza. Root infection by $P$. penetrans reduced carrot growth, but soil inoculation with Glomus sp. spores compensated for the damage caused by P. penetrans. Addition of Glomus spores to soil reduced P. penetrans soil densities by $49 \%$.
\end{abstract}

Key words: Biocontrol, Glomus, Meloidogyne incognita, Pratylenchus penetrans

\section{INTRODUCTION}

Root-knot nematodes (Meloidogyne spp.) and root-lesion nematodes (Pratylenchus spp.) are economically important plant pathogens, causing damage on many crops, mainly expressed as reductions of plant growth and lower yields. Traditionally, diseases caused by nematodes have been managed by nematicides and crop rotation (Trudgill, 1991). However, increasing public and governmental concern about current chemical practices used in intensive agriculture, which are harmful to the environment, has brought attention to alternative control methods such as biocontrol agents to manage diseases caused by nematodes with the aim of maintaining the current standards of quality and production.

Arbuscular mycorrhizas (AM) are soil-borne fungi that establish an obligate mutualistic symbiosis with many plant species. They are characterized by transient dichotomously-branched arbuscules that form inside cortical cells of plant roots from intraradical branch hyphae. Glomus species are the most diverse of the arbuscular mycorrhizas and are found in many soils all over the world. Several studies have reported that Glomus species increase host tolerance in some plant-nematode systems, such as Rotylenchulus reniformis on tomato (Sitaramaiah and Sikora, 1982), Meloidogyne hapla on tree tomato (Cooper and Grandison, 1986), Heterodera glycines on soybean (Tylka et al., 1991) and Pratylenchus coffeae on coffee (Vaast et al., 1998). Localized and induced systemic resistance to soil pathogens have been reported recently in tomato plants colonized by $G$. mosseae BG 12 (Cordier et al., 1998).

On the other hand, early colonization by mycorrhiza is not always beneficial for plant growth in the presence of nematodes (Campubrí et al., 1993; Pinochet et al., 1995) and mycorrhizal establishment can be influenced by nematode invasion of cortical tissues (Smith and Kaplan, 1988; Campubrí et al., 1993; Pinochet et al., 1995). It seems that there is no single response in the interaction mycorrhiza-nematode and that the response depends on various factors, such as nematode, mycorrhiza or plant species, environmental factors, time of mycorrhization and period of exposure to 
the nematode. Therefore, further research is required to select mycorrhizal strains that can protect more effectively against nematode damage in specific crops.

For many years difficulties associated with inoculum production have prevented large-scale use of these bio-protective agents. However, AM products are now commercially available as bio-fertilizers throughout Europe and the U.S.A. and a new strain of AM, Glomus sp. R10 ATCC-74311, with an increased capacity to colonize vegetable roots even under high phosphoric acid levels, has been patented and commercialized recently in Japan by Idemitsu Kosan Co., Ltd. (Narutaki and Miyamoto, 1996).

The main objective of this work was to investigate the possibility of using the mycorrhiza Glomus mosseae BG 12 and Glomus sp. R10 ATCC74311 as protective agents against $M$. incognita on susceptible tomato and $P$. penetrans on carrot. We have studied the effects of the mycorrhiza-nematode interaction on tomato and carrot growth and on pathogen development.

\section{MATERIALS AND METHODS}

Experiment 1: Effects of $G$. mosseae on tomato infected by $M$. incognita. A pot experiment was undertaken in a glasshouse from May to July 1998. Tomato (Lycopersicum esculentum L.) cv. earlymech seeds were germinated in sterilized vermiculite (May 1, 1998) and cultivated in a growth chamber for two weeks. Plantlets were then transplanted to terracotta pots $(9 \mathrm{~cm}$ top diam.; $6 \mathrm{~cm}$ bottom diam.; $8 \mathrm{~cm}$ depth) (May 15, 1998), filled with $240 \mathrm{~g}$ of a sterile clay-sand soil mixture $(5: 3)$, and treated as follows: 1) plants without nematodes or mycorrhiza [=control]; 2) plants inoculated with the mycorrhiza $G$. mosseae at the time of transplanting $[=\mathrm{Gm}] ; 3$ ) plants inoculated with the nematode $M$. incognita at the time of transplanting [=Mi (0)]; 4) plants inoculated with both $M$. incognita and $G$. mosseae at the time of transplanting [Gm-Mi (0)]; 5) plants inoculated with $M$. incognita three weeks after transplanting [Mi (3)] and 6) plants inoculated with G. mosseae at the time of transplanting and $M$. incognita inoculated three weeks after transplanting [=Gm-Mi (3)].

Mycorrhiza was inoculated on May 15, 1998. Spores of G. mosseae BEG12 kindly provided by the European Bank of Glomales were cultured on leek (Allium porrum L.) for two months and leekmycorrhizal root fragments were placed in the planting hole at the time of transplanting (Biermann and Linderman, 1983; Jarstfer and Sylvia, 1992). Control plants (treatments 1, 3 and 5) were treated with leek root fragments but were free of mycorrhiza.

Nematodes were inoculated on May 15 or June 5, 1998. A population of $M$. incognita isolated from a greenhouse tomato field in Granada, Spain, and maintained in a pot culture on tomato $\mathrm{cv}$. earlymech was used as the nematode inoculum. Second stage juveniles (J2) of $M$. incognita were hatched from tomato roots in a mist chamber for seven days by the Seinhorst method (Seinhorst, 1950). For pots receiving nematode inoculum, a population of $1,500 \mathrm{~J} 2\left(\mathrm{P}_{\mathrm{i}}=6.25 \mathrm{~J} 2\right.$ per $\mathrm{g}$ of soil $)$ was delivered to each pot at a depth of $3 \mathrm{~cm}$ from the surface through four holes around the stem of the tomato seedling (Hooper, 1986). Corresponding control plants (treatments 1 and 2) were treated with a suspension from the nematode extraction without nematodes after filtering through a $5 \mu \mathrm{m}$ sieve.

Each treatment was replicated five times and pots were arranged on a glasshouse bench in a randomized-block design, with $10 \mathrm{~cm}$ between them. Temperature in the glasshouse was $16-34^{\circ} \mathrm{C}(16 \mathrm{~h}$ photoperiod) and the experiment was repeated once. Plants were watered daily to field capacity and fertilized once a week with $25 \mathrm{ml}$ of Hoagland's nutrient solution (Hoagland and Arnon, 1950).

On July 24, 1998, 12-week-old tomato plants were harvested ten weeks after transplanting. Shoot lengths and shoot weights were measured at the time of harvest. Root weight was considered to be an inappropriate indicator of plant growth in this study and was not used; in the case of root-knot nematode disease, infected roots tend to be heavier than healthy ones due to gall development, although root growth is reduced. The extent of rootgalling was estimated using the Bridge and Page root-knot rating chart (Bridge and Page, 1980) rating from 0 (no galls) to 10 (all roots severely knotted, no root system, plants dead). Soil contents of each pot were sieved through a $2.5 \mathrm{~mm}$ mesh to separate roots from soil. Second stage juveniles (J2) in the soil were recovered from $100 \mathrm{~g}$ soil sam- 
ples by a combination of the Oostenbrink elutriator, sieving and the cotton-wool filter techniques (Oostenbrink, 1960; Tobar, 1962). Nematodes in roots were determined by staining root samples of $0.25 \mathrm{~g}$ in boiling $0.1 \%(\mathrm{w} / \mathrm{v})$ acid fuchsine in lactic acid, glycerol and distilled water $(1: 1: 1)$ (Bridge et al., 1981). Stained roots were shredded in distilled water and eggs, J2, J3, J4, females and males were counted.

The percentage of the root system colonized by the mycorrhiza (M\%) was assessed in four spare tomato plants three weeks after transplanting-mycorrhization in $0.25 \mathrm{~g}$ root fragments from mycorrhizal tomato plants inoculated with or without $M$. incognita. Roots were cleared with $10 \% \mathrm{KOH}$ in an autoclave liquid cycle at $120^{\circ} \mathrm{C}$ for $20 \mathrm{~min}$ and then stained with chlorazole black-e in lactoglycerol for $15 \mathrm{~min}$ in an autoclave at $120^{\circ} \mathrm{C}$ (Phillips and Hayman, 1970). Colonization of roots was estimated by the grid-line-intersect method (Giovannetti and Mosse, 1980).

Experiment 2: Effects of Glomus sp. on carrot infected by $P$. penetrans. A pot experiment with four treatments, four replicates and carrot (Daucus carota L.) as the host plant was established in a glasshouse from May to July 2000. Treatments in the experiment were as follows: 1) plants without mycorrhiza or nematodes [=control]; 2) plants inoculated with Pratylenchus penetrans $[=\mathrm{Pp}]$; 3) plants inoculated with Glomus sp. [Gs] and 4) plants inoculated with both $P$. penetrans and Glomus sp. [=Gs-Pp].

A clay-loam soil infested with $P$. penetrans $(7$ nematodes per g of soil: $40 \% \mathrm{~J} 2-\mathrm{J} 4 ; 24 \%$ + \% $36 \%$ $\delta \widehat{\delta})$ isolated from a carrot field in Chiba, Japan and maintained in a pot culture on bean (Phaseolus vulgaris L.) was used as the nematode inoculum. The same soil was sterilized at $120^{\circ} \mathrm{C}$ for $20 \mathrm{~min}$ twice and used as the non-nematode control soil and to dilute nematode inoculum in $P$. penetrans treatments $\left(\mathrm{P}_{\mathrm{i}}=0.5\right.$ nematodes per $\mathrm{g}$ of soil $)$.

Inocula of Glomus sp. R10 ATCC-74311 (Idemitsu Kosan Co., Japan) consisted of spores extracted from soil around the roots of sorghum (Sorghum bicolor Moench.) cultured in pots. Spores were extracted from soil by sucrose density gradient centrifugation, washed and stored in tap water at $4^{\circ} \mathrm{C}$ for $24 \mathrm{~h}$ and mixed with soils to obtain a concentration of 5 spores per $g$ of soil (Jarstfer and Sylvia, 1992). Non-mycorrhizal pots were treated with a suspension from the mycorrhizal extraction without mycorrhizal propagules, after filtering through a $5 \mu \mathrm{m}$ sieve.

Three carrot cv. kōyōnigo seeds (Takii Seeds Co., Japan) were planted in plastic pots $(12 \mathrm{~cm}$ diam.; $15 \mathrm{~cm}$ depth) filled with $1,000 \mathrm{~g}$ of sterile soil, Pp-soil, Gs-soil or Gs-Pp-soil (May 15, 2000). After two weeks, only one seedling was left per pot, and all others were removed.

Pots were arranged in a randomized-block design on a glasshouse bench, with $10 \mathrm{~cm}$ between them. Temperature in the glasshouse ranged from $25-35^{\circ} \mathrm{C}$ (16 h photoperiod). Plants were watered daily to field capacity and fertilized once a week with a 5-10-5 liquid fertilizer $(50 \mathrm{ml}$ of $1 / 1,000$ diluted Hyponex, Hyponex Co., Inc., Japan). The experiment was repeated once.

Eight-week-old carrot plants were harvested (July 10, 2000). Carrots were pulled from the soil and plant weights (shoots + storage roots) were recorded.

The soil from each pot was sieved through a 2.5 $\mathrm{mm}$ mesh to separate the roots from the soil. Roots were washed free of soil, finely chopped, mixed thoroughly again with the soils, and stored in plastic bags. After storage for 10 days at $15-20^{\circ} \mathrm{C}$, nematodes were recovered from $20 \mathrm{~g}$ soil samples by a double layer centrifugation method in a sucrose gradient. Soils were mixed thoroughly again before extraction of nematodes.

The percentage of the root system colonized by the mycorrhiza ( $\mathrm{M} \%)$ was assessed in subsamples of $0.25 \mathrm{~g}$ of roots at harvest time by the methods described above.

Statistical analysis. Data were analyzed by oneway or two-way ANOVA. When $F$ values were significant, means were compared by the HSD Tukey test $(p \leq 0.05)$. Kolmogorov-Smirnov and Levene's tests were performed previously to check for normality and homocedasticity, if significant, numerical data were $\log _{10}(x+1)$ transformed and percentages were arcsine square root transformed prior to being analyzed by ANOVA. Kruskal-Wallis or Mann-Whitney tests were used when conditions did not allow the use of parametric statistics. Similarity between experimental runs, tested by preliminary ANOVA using experimental runs as blocks, allowed the data to be combined for subsequent ANOVA. 
Table 1. Effects of mycorrhizal colonization of tomato cv. earlymech roots on plant growth and $M$. incognita reproduction

\begin{tabular}{|c|c|c|c|c|c|c|c|c|}
\hline \multirow[b]{2}{*}{ Treatment $^{\mathrm{a}}$} & \multicolumn{4}{|c|}{ Plant growth ${ }^{\mathrm{b}}$} & \multicolumn{4}{|c|}{ M. incognita reproduction ${ }^{\mathrm{b}}$} \\
\hline & $\begin{array}{l}\text { Shoot } \\
\text { length } \\
(\mathrm{mm})\end{array}$ & $\begin{array}{l}\text { Shoot } \\
\text { weight } \\
\text { (g) }\end{array}$ & $\begin{array}{c}\text { Root } \\
\text { weight } \\
\text { (g) }\end{array}$ & Gall index & $\begin{array}{l}\mathrm{J} 2 \text { per } \\
100 \mathrm{~g} \\
\text { of soil }\end{array}$ & $\begin{array}{c}\mathrm{J} 2+\text { eggs } \\
\text { per } \mathrm{g} \\
\text { of roots }\end{array}$ & $\begin{array}{c}\text { Females } \\
\text { per } g \\
\text { of roots }\end{array}$ & $\begin{array}{l}\text { Eggs } \\
\text { per } \\
\text { female }\end{array}$ \\
\hline Control & $329 a$ & $17.3 \mathrm{a}$ & $9.3 \mathrm{ab}$ & $0 \mathrm{a}$ & - & - & - & - \\
\hline $\mathrm{Gm}$ & $349 a$ & $18.1 \mathrm{a}$ & $10.5 \mathrm{a}$ & $0 \mathrm{a}$ & - & - & - & - \\
\hline $\operatorname{Mi}(0)$ & $*$ & * & $*$ & $10 \mathrm{~b}$ & $*$ & $*$ & * & $*$ \\
\hline Gm-Mi (0) & $*$ & $*$ & $*$ & $10 \mathrm{~b}$ & $*$ & $*$ & $*$ & $*$ \\
\hline $\operatorname{Mi}(3)$ & $203 \mathrm{~b}$ & $12.9 \mathrm{~b}$ & $6.7 \mathrm{~b}$ & $5.7 \mathrm{c}$ & $19,650 \mathrm{a}$ & $5,218 \mathrm{a}$ & $216 \mathrm{a}$ & $114 \mathrm{a}$ \\
\hline Gm-Mi (3) & $323 \mathrm{a}$ & $16.0 \mathrm{ab}$ & $8.2 \mathrm{ab}$ & $3.8 \mathrm{~d}$ & $2,930 \mathrm{~b}$ & $738 b$ & $54 \mathrm{~b}$ & $72 \mathrm{a}$ \\
\hline
\end{tabular}

${ }^{\text {a }} \mathrm{Gm}$, inoculated with Glomus mosseae BG12 at transplanting time; Mi (0), inoculated with M. incognita at transplanting time; Mi (3), inoculated with $M$. incognita three weeks after transplanting.

${ }^{\mathrm{b}}$ Data are the mean of five replicates. Data in the same column followed by the same letter do not differ at the level of $p \leq 0.05$.

* Plants died before harvest.

\section{RESULTS}

\section{Experiment 1: Effects of Glomus mosseae on tomato infected by $M$. incognita}

No significant differences were observed in shoot length or shoot weight between non-mycorrhizal [=control] and mycorrhizal plants without nematodes $[=\mathrm{Gm}]$ (Table 1$)$.

When $M$. incognita was inoculated at the time of tomato transplanting, all plants died before harvest, with or without combined inoculation with the mycorrhizal fungus $G$. mosseae. This was associated with an extensive gall development in the root systems of both treatments, with a gall index of 10 (Table 1).

Three weeks after transplanting, the percentage of the root system colonized by mycorrhiza (M\%) in mycorrhizal tomato without nematode was estimated to be $61.2 \%$. When $M$. incognita was inoculated three weeks after transplanting, shoot length and weight of non mycorrhizal tomato plants $[=\mathrm{Mi}$ (3)] were reduced significantly ( $p \leq 0.05$ ) compared to mycorrhizal $[=\mathrm{Gm}]$ and uninfected plants [=control]. No significant differences were observed in shoot length or weight between mycorrhizal plants with $[=\mathrm{Gm}-\mathrm{Mi}(3)]$ and without $[=\mathrm{Gm}]$ nematode inoculation (Table 1$)$.

The presence of $G$. mosseae within root tissues $[=\mathrm{Gm}-\mathrm{Mi}(3)]$ reduced the gall index compared to non-mycorrhizal plants infected with $M$. incognita $[=\operatorname{Mi}(3)](p \leq 0.05)$ (Table 1$)$.

Numbers of $M$. incognita J2 per $100 \mathrm{~g}$ of soil, $\mathrm{J} 2+$ eggs and females per $\mathrm{g}$ of roots, were always
Table 2. Effects of Glomus sp. and Pratylenchus penetrans on growth of carrot cv. kōyonig $\bar{o}$, nematode and mycorrhiza reproduction

\begin{tabular}{lccc}
\hline Treatment $^{\mathrm{a}}$ & $\begin{array}{c}\text { Plant weight } \\
(\mathrm{g})^{\mathrm{b}}\end{array}$ & $\begin{array}{c}\text { Nematodes per } \\
100 \mathrm{~g}^{\text {of soil }}{ }^{\mathrm{b}}\end{array}$ & $\begin{array}{c}\text { Percentage of } \\
\text { the root system } \\
\text { colonized by } \\
\text { mycorrhiza }^{\mathrm{b}}\end{array}$ \\
\hline Control & $16.7 \mathrm{a}$ & - & - \\
Pp & $4.1 \mathrm{~b}$ & $60 \mathrm{a}$ & - \\
Gs & $17.7 \mathrm{a}$ & - & $60.8 \mathrm{a}$ \\
Gs-Pp & $12.6 \mathrm{a}$ & $31 \mathrm{~b}$ & $41.3 \mathrm{a}$ \\
\hline
\end{tabular}

${ }^{a}$ Pp, Pratylenchus penetrans; Gs, Glomus sp. R10 ATCC74311.

${ }^{b}$ Data are the mean of four replicates. Data in the same column followed by the same letter do not differ at the level of $p \leq 0.05$.

significantly greater in non-mycorrhizal plants than in mycorrhizal plants $(p \leq 0.05)$. There were average reductions of $85 \%$ in the number of $\mathrm{J} 2$ per $100 \mathrm{~g}$ of soil, $86 \%$ in the number of $\mathrm{J} 2+$ eggs per $\mathrm{g}$ of roots and $75 \%$ in the number of females per $g$ of roots in the presence of G. mosseae (Table 1).

The number of eggs per female was $37 \%$ lower in mycorrhizal plants compared to non-mycorrhizal plants, but the differences were not significant at the $p \leq 0.05$ level.

\section{Experiment 2: Effects of Glomus sp. on carrot infected by $P$. penetrans}

Carrot weight was significantly reduced $(p \leq 0.05)$ in $P$. penetrans treatment $[=\mathrm{Pp}]$ com- 
pared to control or Glomus [=Gs] (Table 2). Weight of plants inoculated with both Glomus sp. and $P$. penetrans [ $=\mathrm{Gs}-\mathrm{Pp}]$ was still $25 \%$ lower than the controls, but the differences in weight were not significant at the $p \leq 0.05$ level.

Final nematode populations in Glomus treatments $[=\mathrm{Gs}-\mathrm{Pp}]$ were half the number present in non-Glomus treatments $[=\mathrm{Pp}]$ (Table 2). No significant differences were observed in the percentage of roots colonized by the mycorrhiza.

\section{DISCUSSION}

Tomato plants inoculated with the pathogen $M$. incognita at the time of transplanting were not provided with any protection from the arbuscular mycorrhiza G. mosseae. Plants from both treatments, with and without mycorrhiza, died before harvest. This was already reported for other simultaneous AM-nematode inoculations, which had failed in enhancing tolerance against nematodes (Abha and Shukla, 1997; Vaast et al., 1998). Root colonization by AM takes 2 to 4 weeks, but root-knot nematodes penetrate roots in a matter of hours. Nematodes, therefore, have an advantage in the competition for root space and further reproduction.

Significant plant growth reductions were observed in tomato infected with $M$. incognita three weeks after transplanting and in carrot plants infected with $P$. penetrans, in the absence of mycorrhizal inoculation. A beneficial effect was observed when tomato plants were pre-mycorrhized and when mycorrhizal spores were added to the soil where carrots were grown. Since control plants were watered with the same microflora suspension without mycorrhiza, these effects should be directly linked to mycorrhizal inoculation and not to other microorganisms or nutrients associated with the inoculum.

The lower gall index and final $M$. incognita densities in soil and roots seven weeks after $M$. incognita inoculation show a suppressive effect on nematode populations by the pre-mycorrhization of tomato. In addition, application of mycorrhizal spores to the soil proved to be useful in reducing $P$. penetrans densities on carrot. These results agree with previous reports on suppression of other rootknot and root-lesion nematode populations by mycorrhizal species, such as $M$. hapla in onion (MacGuidwin et al., 1985), M. incognita in tree tomato (Cooper and Grandison, 1986) and banana (Jaizme-Vega et al., 1997) and Pratylenchus spp. on several perennial crops (Pinochet et al., 1996).

The number of eggs per female was reduced in mycorrhizal plants by $38 \%$ but differences were not significant at the $p \leq 0.05$ level. Sitaramaiah and Sikora (1982) reported that the number of eggs per egg mass of $R$. reniformis was reduced in G. fasciculatum-colonized tomato plants. An inhibition in $M$. incognita development was also observed in mycorrhizal tobacco and tomato plants (Sikora, 1978; Rao et al., 1997). These results could be explained if we consider that the amount of nutrients available within the roots for endophytes has to be shared by two organisms when roots are infected by Meloidogyne and Glomus, and in that case, the intake of nutrients by Meloidogyne females would be reduced, having a detrimental effect on the number of eggs produced by females.

Mechanisms that underlay the beneficial effects of mycorrhiza against nematode attack could involve competition for space and anatomical changes due to mycorrhization that could affect nematode penetration (Azcón-Aguilar and Barea, 1996). However, other modifications linked to mycorrhizal inoculation could also occur and further research is needed on these subjects.

Our results show that an early mycorrhizal inoculation of tomato plants is highly beneficial to plant development in soils infested with $M$. incognita by increasing the host tolerance to the pathogen. Pre-colonization with mycorrhiza in plants that are transplanted as seedlings could benefit from this increased tolerance to root-knot nematodes. Simultaneous mycorrhizal inoculation with nematodes was not effective in protecting tomato plants against $M$. incognita but conferred some protection to carrot infected with $P$. penetrans. Direct application of mycorrhizal spores to the soil can be effective in protecting against nematode damage depending on the virulence of nematode species, mycorrhizal dependency of the host crop and bio-protective potential of the mycorrhizal strain.

\section{ACKNOWLEDGEMENTS}

The authors thank Dr. Christelle Cordier (INRA, Dijon, France) and Dr. Motoshi Suzuki (Idemitsu Kosan Co., Japan) for providing us with mycorrhizal inoculum and Dr. Masanori Saito (National Grassland Research Institute, Japan) for his valuable information on obtaining the mycorrhizal inoculum. 
The first author is also grateful to the Japan Science and Technology Corporation (JST) for a post-doctoral STA fellowship in Japan that provided funds for this study.

\section{REFERENCES}

Abha, M. and B. N. Shukla (1997) Interactions between Glomus fasciculatum and Meloidogyne incognita on tomato. J. Myco. Plant Pathol. 27: 199-202.

Azcón-Aguilar, C. and J. M. Barea (1996) Arbuscular mycorrhiza and biological control of soil borne plant pathogens - an overview of the mechanisms involved. Mycorrhiza 6: 457-464.

Biermann, B. and R. G. Linderman (1983) Use of vesicular-arbuscular mycorrhizal roots, intraradical vesicles and extra-radical vesicles as inoculum. New Phytol. 95: 97105.

Bridge, J. and S. L. Page (1980) Estimation of root-knot nematode infestation levels on roots using a rating chart. Trop. Pest Manage. 26: 296-298.

Bridge, J., S. L. Page and S. Jordan (1981) An improved method for staining nematodes in roots. Rep. Rothamsted Exp. Stn. Part 1: 171.

Campubrí, A., J. Pinochet, C. Calvet and V. Estaún (1993) Effects of the root-lesion nematode Pratylenchus vulnus and the vesicular arbuscular mycorrhizal fungus Glomus mosseae on the growth of three plum rootstocks. Plant Soil 153: 223-229.

Cooper, K. M. and G. S. Grandison (1986) Interaction of vesicular-arbuscular mycorrhizal fungi and root-knot nematode on cultivars of tomato and white clover susceptible to Meloidogyne hapla. Ann. Appl. Biol. 108: 555566.

Cordier, C., M. J. Pozo, J. M. Barea, S. Gianinazzi and V. Gianinazzi-Pearson (1998) Cell defense responses associated with localized and systemic resistance to Phytophthora parasitica induced in tomato by an arbuscular mycorrhizal fungus. Mol. Plant-Microbe Interact. 11: 10171028.

Giovannetti, M. and B. Mosse (1980) An evaluation of the techniques for measuring vesicular arbuscular mycorrhizal infection on roots. New Phytol. 84: 489-500.

Hoagland, D. and D. I. Arnon (1950) The water culture method for growing plants without soil. Calif. Agric. Exp. Stn. Circ. 347: 1-32.

Hooper, D. J. (1986) Laboratory methods for work with plant and soil nematodes. Reference Book 402. Ministry of Agriculture, Fisheries and Food Technical Bulletin 2: 133-154.

Jaizme-Vega, M. C., P. Tenoury, J. Pinochet and M. Jaumot (1997) Interactions between the root-knot nematode Meloidogyne incognita and Glomus mosseae in banana. Plant Soil 196: 27-35.

Jarstfer, A. G. and D. M. Sylvia (1992) Inoculum production and inoculation strategies for vesicular-arbuscular mycorrhizal fungi. In Soil Microbial Ecology: Applications in Agriculture and Environmental Management (B. Metting ed.). Marcel Dekker, New York, pp. 349-377.

MacGuidwin, A. E., G. W. Bird and G. R. Safir (1985) Influence of Glomus fasciculatus on Meloidogyne hapla in- festing Allium cepa. J. Nematol. 17: 389-395.

Narutaki, A. and J. Miyamoto, inventors; Idemitsu Kosan Co., assignee (1996) VA mycorrhizae fungus Glomus sp R10 having resistance to phosphoric acid and culturing method of plant using the same fungus. Japanese patent JP8168318.

Oostenbrink, M. (1960) Estimating nematode populations by some selected methods. In Nematology (J. N. Sasser and W. R. Jenkins eds.). Chapell Hill, Univ. N. Carolina Press, pp. 85-102.

Phillips, J. M. and D. S. Hayman (1970) Improved procedures for clearing roots and staining parasitic and vesicular-arbuscular mycorrhizal fungi for rapid assessment of infection. T. Brit. Mycol. Soc. 55: 158-161.

Pinochet, J., C. Calvet, A. Campubrí and C. Fernández (1995) Growth and nutritional response of Nemared peach rootstock infested with Pratylenchus vulnus and the mycorrhizal fungus Glomus mosseae. Fund. Appl. Nematol. 17: 205-210.

Pinochet, J., C. Calvet, A. Campubrí and C. Fernández (1996) Interactions between migratory endoparasitic nematodes and arbuscular mycorrhizal fungi in perennial crops: A review. Plant Soil 185: 183-190.

Rao, M. S., P. P. Reddy, N. Somasekhar and M. Nagesh (1997) Management of root-knot nematodes, Meloidogyne incognita in tomato nursery by integration of endomycorrhiza, Glomus fasciculatum with castor cake. Pest Manage. Hortic. Ecosyst. 3: 31-35.

Seinhorst, J. W. (1950) De betekenis van de toestand van de grond voor het optreden van aantasting door het stengelaaltje (Ditylenchus dipsaci (Kühn) Filipjev). Tijdsch. Plantenz. 56: 289-348.

Sikora, R. A. (1978) Einfluß der endotrophen Mykorriza (Glomus mosseae) auf das Wirt-Parasit-Verhältnis von Meloidogyne incognita in Tomaten. Z. Pflanzenk. Pflanzen. 85: 197-202.

Sitaramaiah, K. and R. A. Sikora (1982) Effect of the mycorrhizal fungus Glomus fasciculatus on the host-parasite relationship of Rotylenchulus reniformis in tomato. Nematologica 28: 412-419.

Smith, G. S. and D. T. Kaplan (1988) Influence of mycorrhizal fungus, phosphorus and burrowing nematode interactions on growth of rough lemon citrus seedlings. J. Nematol. 20: 539-544.

Tobar, A. (1962) Modificación al método del cotton-wool filter de Oostenbrink. Rev. Ibér. Parasitol. 22: 329-334.

Trudgill, D. L. (1991) Resistance and tolerance of plant parasitic nematodes in plants. Ann. Rev. Phytopathol. 29: 167-192.

Tylka, G. L., R. S. Hussey and R. W. Roncadory (1991) Interactions of vesicular-arbuscular mycorrhizal fungi, phosphorous and Heterodera glycines on soybean. J. Nematol. 23: $122-133$.

Vaast, P., E. P. Caswell-Chen and R. J. Zasoski (1998) Influences of a root lesion nematode, Pratylenchus coffeae, and two arbuscular mycorrhizal fungi, Acaulospora mellea and Glomus clarum on coffee (Coffea arabica L.). Biol. Fert. Soils 26: 130-135. 